\title{
Government Size, Trade Openness, and Output Volatility: A Case of Fully Integrated Economies
}

\author{
Eiji Fujii \\ CESIFO WORKING PAPER NO. 5563 \\ CATEgory 1: Public FinAnCE \\ OCTOBER 2015 \\ An electronic version of the paper may be downloaded \\ - from the SSRN website: Www.SSRN.com \\ - from the RePEc website: Www.RePEc.org \\ - from the CESifo website: www.CESifo-group.org/wp
}




\title{
Government Size, Trade Openness, and Output Volatility: A Case of Fully Integrated Economies
}

\begin{abstract}
Government is often considered the safe sector of an open economy that provides households with insurance against external risk exposure. Among highly integrated economies, however, households should be able to exploit common financial markets to insure themselves. In this paper we examine the relationship between government size, trade openness, and output volatility across fully integrated economies using Japan's regional income accounting and public finance data. The contributions of the government- and market-based insurances to interregional risk sharing are also estimated. The empirical results reveal some unique aspects of the state-market interactions under full economic integration with vertical fiscal imbalance.
\end{abstract}

JEL-Code: H100, H700, F400.

Keywords: government size, output volatility, risk-sharing, trade openness, vertical fiscal imbalance.

\author{
Eiji Fujii \\ School of Economics \\ Kwansei Gakuin University \\ 1-155 Uegahara Ichiban-cho, Nishinomiya \\ Japan - Hyogo 662-8501 \\ efujii@kwansei.ac.jp
}

This version: October 2015

The author gratefully acknowledges financial support for this research by the Grant-in-Aid for Scientific Research (No. 25285087) from the Japan Society for the Promotion of Science. He also thanks Mark Spiegel, Yin-Wong Cheung, and the participants of the MIFN 2014 Workshop at IÉSEG-School of Management in Paris for helpful comments and discussion. All remaining errors are solely of the author's. 


\section{Introduction}

In a world with complete capital markets, agents can insure themselves against idiosyncratic shocks by holding geographically diversified portfolios. The extant international evidence on consumption correlations (Backus, Kehoe, and Kydland, 1992), asset portfolio diversification (French and Poterba, 1991), and saving-investment correlations (Feldstein and Horioka 1980) suggests, however, that the world capital markets are not integrated well enough to induce sufficient risk sharing among households in different countries. Under such circumstances, there is room for governments to assume a risk-reducing role. The demand for the state provision of insurance will be greater in countries with more substantial external risk exposure, other conditions held equal.

In a seminal paper, Rodrik (1998) demonstrates that countries with a greater extent of trade openness tend to have a larger size of government relative to gross domestic product (GDP). Noting that trade openness reflects susceptibility to external shocks, he attributes the seemingly paradoxical phenomenon of a larger government in a more liberalized economy to a stronger demand for social insurance under greater external risk exposure. Further, Galí (1994) and Fatás and Mihov (2001) provide empirical evidence that an increase in government size exerts significant output stabilizing effects. That is, economies with a larger share of the government sector in GDP tend to have more stable output growth than those otherwise.

An important implication of the aforementioned studies is that market liberalization does not necessarily reduce the importance of the government sector for an open 
economy. Instead, it is likely accompanied by enhanced presence of state in provision of insurance against external risk and output fluctuations. ${ }^{1}$

In the extant literature, the determinants and implications of government size are examined mostly by cross-country analyses. Thus, the empirical evidence is accumulated on samples of economies that are partially liberalized yet still segmented to varying degrees by market barriers and political borders. It is unclear if the findings of these studies retain relevance when economic integration advances fully in real and financial markets as well as in monetary and fiscal policy spheres.

On the one hand, liberated cross-border flows of goods and services enlarge mutual trade exposure, making economies more interdependent and subjective to external shocks. On the other hand, households will enjoy unhindered access to integrated financial markets, irrespective of the location of their residence, as investment and credit demands arise. ${ }^{2}$ Unless prohibited, they may also choose to re-locate themselves across regional boundaries in response to asymmetric shocks. To the extent that economic integration weakens the effects of borders by enabling households to better diversify their income portfolios, there should be less demand for governments to intervene by providing risk-coping means.

On the policy ground, integration may be deepened by adoption of a common currency, which will eliminate the nominal exchange rate volatility to boost the cross-border transactions. Since adoption of a common currency also abolishes monetary policy autonomy, additional weights will be placed on fiscal policy to respond to idiosyncratic shocks and region-specific economic conditions. If economic

1 Rodrik (2011) highlights the complementarity between market and state as an essential feature of the process of economic globalization.

2 See Svaleryd and Vlachos (2002) for evidence on positive interdependence between trade liberalization and financial market development. 
integration is fortified further by fiscal consolidation, interregional taxes and transfers serve as an additional insurance device by which risks are shared cross-regionally. All in all, full economic integration can simultaneously increase mutual risk exposure, access to market-based insurance, and a potential of state-provision of risk-sharing arrangements. The final outcome is an empirical matter.

This paper examines the relationship between government size, trade openness, and output volatility across fully integrated economies by using Japan's regional income accounting and public finance data. Forty-seven prefectures in Japan constitute an illuminating case of integrated economies with common product and financial markets, a single currency, and a unified fiscal system featuring large-scale vertical imbalance. A desirable feature of the Japanese data is that they contain direct measures of regional government size while allowing decomposition in two ways: (a) between consumption and investment expenditures; and (b) between independently-attained local revenue and centrally-provided transfer revenue.

To anticipate, our chief findings are as follows. In clear contrast to the international evidence, prefectures with greater trade openness are found to have smaller governments. This negative effect of openness is robust to inclusion of various controls. By examining government size in components, we find that the distribution of a main center-to-local transfer is driven almost entirely by non-economic factors. Further, we find only limited evidence on the government size effect for regional output stabilization. In sharing risks across prefectures, 14 percent of regional output fluctuations are smoothed via the tax and transfer channel, whereas only about 10 percent are done by capital market. In dealing with idiosyncratic output shocks, the Japanese households rely heavily on credit market (i.e. savings and loans) with its share 
exceeding 65 percent. The estimates attest shifts in the means of risk sharing from capital market to fiscal policy and credit market as the economy enters the stagnant deflationary era.

To arrive at these conclusions, the rest of the paper is organized as follows. Section 2 contains a selective literature review. Section 3 describes the features of Japan's local public finance and the empirical data. In section 4, we examine the determinants and implications of government size while paying special attentions to the effects of trade openness and the implications of vertical fiscal imbalance. Section 5 considers the effectiveness of government in output stabilization and provision of risk-sharing arrangements. Finally, section 6 presents concluding remarks.

\section{Selective literature review}

As a focal economic and policy issue, government size is analyzed from various perspectives in the literature. It is beyond the scope of the current study to provide a comprehensive review of the voluminous literature. Instead, this section has a parsimonious objective to review a selective set of preceding studies that guides us in considering the determinants and implications of government size.

By demonstrating that trade openness leads to a larger size of government, Rodrik (1998) argues that government spending plays the role of an insulator from externally emanating risk. His investigation is explored further by a number of subsequent studies in a few dimensions: disaggregation of government expenditures (Shelton, 2007; Benarroch and Pandey, 2012); use of large panel data (Ram, 2009); and addition of financial openness measures (Kimakova, 2009). Overall, they report mixed evidence on the positive openness-government size nexus and its account forwarded by Rodrik 
Alesina and Wacziarg (1998) maintains an alternative view that the positive openness-government association is driven by the economy size effect. A larger economy, by being more self-sufficient, can afford being less open. Thus, in the presence of fixed costs and economies of scale in the supply of non-rivalry public goods, a larger economy tends to have a smaller share of government expenditure in GDP. ${ }^{3}$

There are other important determinants of government size than openness. Wagner's law suggests that the demand for government services is income elastic. ${ }^{4}$ If a rising income level leads to increasing demand for welfare state, the share of government expenditure in output can also rise. Similarly, it is conceivable that differences in regional income levels lead to varying sizes of government.

Variation in demographic conditions can also lead to differences in government size. Total population partly captures the market size effect of Alesina and Wacziarg (1998). Also, some studies (Tait and Heller, 1982; Ram, 1987; Heller and Diamond, 1990) find that the dependency ratio affects government size.

The size of government, determined by the various factors above, can have crucial economic implications. ${ }^{5}$ In the long-run, fiscal policy is related to the level of economic development and the rate of economic growth (Easterly and Rebelo, 1993). A more commonly perceived role is the short-run stabilization of business cycle fluctuations. The empirical evidence indicates that government size and GDP volatility are negatively

\footnotetext{
${ }^{3}$ It should be noted that, as Alesina and Wacziarg (1998) acknowledges, their account and Rodrik's are not necessarily mutually exclusive.

${ }^{4}$ For evidence on Wagner's law, see Abizadeh and Gray (1985), Ram (1987), and Brückner, Chong, and Gradstein (2012) among others.

${ }^{5}$ Differences in political accountability and electoral system can also generate variation in government size across countries (Persson and Tabellini, 1999). However, for the intra-Japan investigation, they are unlikely to play a chief role.
} 
correlated (Galí, 1994; Fatás and Mihov, 2001). ${ }^{6}$ In other words, economies with a larger government share in output tend to have more stable growth.

One common feature among most previous studies is that the researchers conduct cross-country analyses based on sample economies that are segmented by national borders. ${ }^{7}$ In general, households in different countries do not share common financial markets to insure themselves against risks. Neither do they have an integrated tax and transfer system that can be used as a risk-sharing device. These conditions, however, shift as market liberalization and economic integration proceed regionally and globally. For instance, in the Euro-zone where the market and currency integration is established, the recent debt crisis re-kindled the debates over the necessity of a fiscal union as an insurance scheme. ${ }^{8}$ For implications and potential lessons, it is worth investigating the experiences of the economies that are well integrated in real and financial markets as well as unified on the monetary and fiscal policy grounds.

\section{Regional economies and public finance in Japan}

\subsection{The structure and issues}

Japan consists of forty-seven prefectures which are geographically defined administrative units largely corresponding to states in the US. ${ }^{9}$ No legal restrictions are imposed on flows of goods, services, capital, or labor across or within the prefectures.

\footnotetext{
${ }^{6}$ While Galí (1994) theoretically finds that the relationship between government size and output volatility is ambiguous, his empirical results suggest negative correlations.

7 An important exception is the intra-US investigation of Fatás and Mihov (2001).

${ }^{8}$ See, for instance, Bordo, Jonung, and Markiewicz (2013).

${ }^{9}$ Within a prefecture there are municipalities (i.e. cities, towns, and villages) as smaller administrative units. For the remainder of this paper, the prefectural and municipal governments combined are referred to as the local government.
} 
An eminent feature of Japan's public finance is the large-scale vertical fiscal imbalance. While approximately two thirds of the total government expenditure occurs locally, more than sixty percent of tax revenue is collected centrally. ${ }^{10}$ The vast majority of local governments do not have their own tax revenue to fully finance their expenditure. To fill in the gap, the central government appropriates certain percentages of the national tax revenue as a fund for the transfer to the local governments. ${ }^{11}$ This transfer is termed the local allocation tax (LAT) grant. In addition, upon applications by the local governments, the national treasury disbursements (NTD) are paid out to local governments as subsidies with pre-designated usages. ${ }^{12}$ The LAT and NTD are the main transfer devices of the central government. They together comprise about one third of the total revenue of all local governments.

Since the amount of the transfers depends on the national tax revenue that fluctuates with business cycles, when necessary the central government permits the local governments to issue bonds as an additional source of revenue. Though issued locally, these bonds are not considered an independent revenue source of the local governments for two reasons: the issuance requires the central government's permission; and their redemption fees are commonly financed by the LAT in the future years.

In principle, fiscal decentralization is beneficial in that it induces provision of public goods and services closely matching regional needs and preferences (Oates, 1972; 1999). In the current case, the local governments can decide the usages of the LAT by taking

10 See Ministry of Internal Affairs and Communications (2014) for details.

11 Specifically, 32 percent of the income and alcohol tax revenue, 34 percent corporate tax revenues, 29 percent of consumption tax revenue, and 25 percent tobacco tax revenue are used as a fund.

12 The main usages of the NTD include social welfare payment, compulsory educational expenses, child-rearing support, recovery and reconstruction from earthquakes, and ordinary construction work expenses. The allocative decisions are made by the corresponding ministries within the central government. 
region-specific factors into considerations. Other potential benefit of the decentralization is that it can spur inter-regional competition, which exerts the disciplinary effect on the local governments to enhance efficiency and accountability.

There is also a downside. Within a country, a marginal demand effect created by a fiscal expansion in one region can dissipate to others. ${ }^{13}$ The externality makes it less enticing for the local governments to pursue stabilization at their own cost. Also, the Ricardian equivalence discourages countercyclical deficits even when desirable since intra-national migration is unrestricted (Sala-i-Martin and Sachs, 1992). ${ }^{14}$

Perhaps a more serious concern for Japan's case is moral hazard. Under the current system, the amount of the LAT provided to the local governments is determined in accordance with the estimates of the revenue and expenditure in local public finance. Specifically, the difference between the estimated fiscal demand (termed "standard financial demand") and the expected local tax revenue (termed "standard financial revenue”) determines the "regular allocation tax amount”. ${ }^{15}$

Obviously, this allocation method gives the local governments an incentive to inflate their fiscal demand and not to raise tax revenue on their own. Thus, the disciplinary effect of enhancing inter-regional competition can be pre-empted. Sato (2002) highlights the discretionary nature of the LAT and the perverse incentives they create for local governments by softening the local budgets ex post. ${ }^{16}$ The interaction between

13 See Brückner and Tuladhar (2013) for an empirical assessment of the spillover effects of local government spending in Japan.

14 After benefiting from the fiscal spending, households anticipating a future tax hike can migrate to other prefectures.

${ }^{15}$ See Ministry of Internal Affairs and Communications (2014).

16 See Persson and Tabellini (1996) for more general analyses of moral hazard in a fiscal federation with two levels of government. 
the local and central governments introduces an additional analytical dimension to our investigations.

\subsection{Data}

The Annual Report on Prefectural Accounts published by the Cabinet Office of Japan provides the prefectural income accounting data. From the 2012 CD-ROM of the report, we extract the data on the prefectural GDP, gross prefectural income (GPI), disposable income (DI), and the GDP components including private final consumption, government final consumption, gross fixed public capital formation, gross fixed government capital formation, import from and export to other prefectures. In addition, we use the population and sectoral GDP data. The sample period is set from 1996 to 2009 due to data availability.

Additional local public finance data are obtained from the Regional Statistics Database of the Official Statistics of Japan. Specifically, we use the data on the amounts of locally-collected revenue, LAT received, and NTD received. The data on dependency ratio and area size are also obtained from the same database. The Data Appendix provides further details of the data we use.

It is worth highlighting the desirable features of the Japanese data. Fatás and Mihov (2001) notes that for the US it is impossible to obtain accurately disaggregated state-level figures of government spending. Consequently, they use the federal tax revenue as a proxy measure of the state government size. In contrast, our data contain direct measures of the government consumption and investment by prefecture. Furthermore, the amounts of the independent local revenue and the transfer received from the central government are also revealed. ${ }^{17}$ The disaggregation by revenue source

17 The independent local revenue consists mostly of the prefectural and municipal tax 
allows us to examine the roles played by the local and central governments in the vertically imbalanced structure.

Another advantage of the Japanese data is the availability of local (government and private) consumption figures. For the US, annual retail sales are routinely used as a proxy for the unobserved state consumption (Bayoumi and Masson, 1995; Asdrubali, Sørensen, and Yosha, 1996). Reliance on such a proxy measure is unnecessary when estimating the extent of the intra-Japan risk sharing.

\section{Government size, trade openness, and vertical fiscal imbalance}

\subsection{Determinants of government size}

We initiate our empirical exploration by estimating the effects of the following factors on the size of the local governments: trade openness, per capita income, total population, dependency ratios, and area size of the prefectures. To avoid endogeneity, we estimate a cross-sectional regression equation in a similar fashion to Rodrik (1998)

$$
G_{0 V 0609}=\alpha+\beta \text { OPEN }_{i}+\lambda P C Y_{i}+\gamma P O P_{i}+\tau D E P_{i}+\theta A R E A_{i}+\varepsilon_{i},
$$

for which GOV0609 is the 2006-2009 averages of government size gauged by using the following measures: (a) government final consumption; (b) gross fixed public capital formation; (c) gross fixed government capital formation in prefecture $i$ relative to its GDP. ${ }^{18}$ The sum of (a) and (b) relative to GDP is referred to as the total size of

revenues including those on the inhabitant tax, enterprise tax, local consumption tax, real estate acquisition tax, automobile tax, and fixed asset tax.

18 The following prefectural GDP accounting identities hold: GDP $\equiv$ private final consumption + government final consumption + gross capital formation (GCF) + export - import; GCF $\equiv$ gross fixed capital formation (GFCF) + inventory changes; GFCF $\equiv$ Gross fixed (GF) private capital formation + GF public capital formation (GFPCF); and GFPCF $\equiv$ GF residential capital formation + GF business equipment capital formation + GF government capital formation. 
government. For the independent variables, we use the 1996-2005 averages. OPEN $N_{i}$ is trade openness measured by the sum of export to and import from other prefectures relative to i's GDP. $P C Y_{i}$ is per capita prefectural income. $P O P_{i}$ and $D E P_{i}$ are the total population and the average dependency ratio, respectively. AREA indicates the geographical area size in hectare. $P C Y_{i}, P O P_{i}$, and $A R E A_{i}$ are in logged values.

The results are summarized in Table 1 . The effect of trade openness on the size of local governments, whether by the consumption, investment, or total measures, is significantly negative. That is, a prefecture with a greater GDP share of trade (in 1996-2005) tends to have smaller government consumption and investment (in 2006-2009) relative to its GDP. ${ }^{19}$ The finding starkly contrasts with the previous international evidence of the positive association. Meanwhile, the negative openness effect is in line with a general perception that the extent of government intervention is less in more open and competitive economies. We extend our discussion on the results in the next sub-section where we sort out factors behind the trade openness effect.

The effects of per capita income and population size are also significantly negative. A wealthier prefecture tends to have smaller government. ${ }^{20}$ The effect is significant particularly for government consumption. Given that our sample consists of regional economies within a developed country, the result should not be regarded as direct evidence against Wagner's law which may well apply to economies at different stages

\footnotetext{
19 For robustness, we also used the 2006-2007 averages for the dependent variable to remove possible effects of the 2008 world financial crisis. The results turn out to be qualitatively very similar, and hence, they are not reported to conserve space.

${ }^{20}$ Similar negative results are also reported in Rodrik (1998).
} 
of development. The negative coefficient on total population is consistent with the economy size effect emphasized by Alesina and Wacziarg (1998).

The effect of dependency ratio is not significant in any case. The area size exerts significantly positive effect on the government investment but not on consumption. One interpretation is that the cost of investment on public infrastructure tends to rise at an increasing rate as the physical area it covers expands.

Overall, the results thus far suggest that a more trade-exposed, wealthier, and more densely populated prefecture has a smaller share of government in its output. We scrutinize further the negative openness effects below.

\subsection{Effects of trade openness and industrial specialization}

A prefecture can have a high trade to GDP ratio due to (a) regional factor endowments to induce specialization in production and variety in consumption/input baskets; (b) proximity to large markets in other prefectures; and (c) competitiveness of local products that is not attributable to (a) or (b). We refer to (c) as the "residual" effect.

While the benefits of specialization are well known, more specialized production will also lead to greater risk of volatile output movements as compared to diversified production. Consequently, there will be stronger demand for insurance to cover the output risk in economies with a higher extent of specialization. Using data for various groups of regions and countries, Kalemli-Ozcan, Sørensen, and Yosha (2003) finds evidence that a higher degree of insurance within a group is positively associated with a greater extent of industrial specialization. In the context of the current study, if prefectures with a highly specialized production structure seek insurance against output 
risk via the fiscal channel, they are also likely to have a larger government size holding other things equal.

For further insight, we devise additional variables to capture the effects of (a) and (b) above to supplement (1). While it is difficult to directly measure the regional factor endowments, the extent of specialization can be quantified from the sectoral GDP data. Specifically, we adopt the index proposed by Krugman (1991)

$$
S P_{i}=\sum_{k}\left|S_{k, i}-S_{k, A}\right|,
$$

for which $s_{k, i}$ and $s_{k, A} \equiv \sum_{j \neq i} s_{k, j} / 46$ are the output share of sector $k$ in prefecture $i$ and the average of all other prefectures, respectively, for a given year. The index takes a greater value for a prefecture with a more distinctive production structure relative to others. We calculate the 1996-2005 averages of $S P_{i}$ to use as a control. ${ }^{21}$ The list of the sectors is provided in the Data Appendix.

To capture the effects of proximity to large markets elsewhere, we use the neighboring prefectures' population size and the total distance from the ten most populated prefectures both in logged values. ${ }^{22}$ The inter-prefectural distance is measured by the geographical distance between the prefectural capitals.

The three newly devised variables above are added to (1) as controls to identify which factors of the trade openness significantly affect government size. The results are summarized in Table 2.

\footnotetext{
${ }^{21}$ We also considered a similarly motivated index of Kalemli-Ozcan et al. (2003) that gauges the extent of specialization within manufacturing industry. The index is constructed using the sub-sectoral output shares in the total manufacturing output. The results appear similar but less unequivocal due presumably to the fact that the manufacturing sector comprises smaller part of the traded sector within a country than across countries.

${ }^{22}$ See the data appendix for details.
} 
Of the additional controls, only the specialization index is found statistically significant at the conventional level for all measures of government size. Intensification of sectoral specialization is associated with a larger government size. High production concentration on selected sectors makes the prefectural output potentially more exposed to sector-specific shocks. In this sense, the positive specialization coefficient estimates can be consistently interpreted with the social insurance account of Rodrik (1998).

Importantly, the negative effect of the trade openness variables is quite robust to inclusion of the additional control variables. The trade openness effect in Table 2 is neither the effects of trade restrictions, specialization, nor proximity to large markets. Neither is it the effect of market size since the total trade is normalized by the GDP and the prefectural population and area sizes are controlled for. Our interpretation is that the "residual" trade openness effect captures in part the competitiveness of the local economy which tends to reduce reliance on the government sector, and hence, obtains a significant negative coefficient as estimated.

We note that the negative trade openness effect estimates should not be viewed as direct contradiction to Rodrik (1998). In the intra-national context, the private insurance via financial markets and cross-prefectural labor migration can be a more effective option for households than lobbying and voting in coping with risks. If the private market channels are restricted, however, as they typically are in international cases, the social insurance account is plausible where the forces of national political economy can heavily influence the government behavior and its scale. In this sense, our findings are complements to Rodrik’s.

\subsection{Implications of vertical fiscal imbalance}


As already noted, a substantial portion of the local government expenditure is financed by the transfers from the central government. Thus, the measured local government sizes are actually behavioral composites of the local and central governments. It is, therefore, informative to decompose the size of local government by revenue source. Specifically, we use the data on the amounts of the independent local revenue (i.e. mostly local tax revenue), the LAT, and the NTD received. ${ }^{23}$ Due to data constraints, we are unable to include the local bonds as an additional component.

We replace $G O V 0609_{i}$ in (1) by the three component measures in their ratios to the prefectural GDP to report the results in Table 3. A few observations are in order. The estimates in column 1 indicate that prefectures with a higher income level and larger population tend to have a greater amount of the local revenue relative to GDP. A high income level and a large population size constitute amplitude of local tax bases, and hence, lead to greater fiscal revenue. On the other hand, the geographical area size exerts a significant negative effect. A conjectural account is that high population density (i.e. a smaller area size when population held constant) generates agglomeration effects to boost the local tax revenues such as those of the enterprise tax, local consumption tax, real estate acquisition tax, and fixed asset tax. The effect of trade openness is also negative though not significant at the conventional level.

The results on the LAT and NTD in columns 3 and 5, respectively, indicate that the two components, while both provided by the central government, are determined by rather different forces. The NTD estimates reveal that openness, population, and area sizes exert significant effects in a qualitatively similar fashion to the local revenue

\footnotetext{
${ }^{23}$ These component figures are available only in nominal series. Therefore, we take their ratios to the nominal GDP and deflate them by the prefectural GDP deflators.
} 
results in column 1. In contrast, the results on the LAT suggest that none of the regressors exert significant effects on the LAT. In addition to the insignificance of the coefficient estimates, the low adjusted r-squares estimate indicates that the regression model has little explanatory power for the difference in the LAT across prefectures.

When the additional controls are included to isolate the residual openness effect, the results in columns 2, 4 and 6 suggest that the LAT is distinct also in that the sectoral specialization has no relevance. Meanwhile, the LAT and NTD share a common attribute that they tend to rise in remotely located prefectures. The positive neighboring population effects, albeit of only moderate significance, imply externality in the transfer distribution that may spur geographical concentration of the centrally-allocated resources.

As discussed in sub-section 3.1, the amount of the LAT is determined by differences between the estimated fiscal demand and the expected local tax revenue. While the amount is decided ultimately by the central government, the local governments can affect the bases against which the fiscal demand and local tax revenue are estimated. Thus, it is virtually a product of strategic interactions between the central and local governments. Our estimates suggest that the outcome is hard to model by observable economic characteristics of the prefectures other than remoteness.

\section{Regional stabilization and inter-regional risk sharing}

\subsection{Regional output stabilization}

In the following sub-sections, we turn our attention to the effectiveness of government of fully integrated economies in stabilizing regional output and enabling risk-sharing by households in the face of regional fluctuations. The current sub-section 
examines if an increase in government size exerts significantly stabilizing effects on prefectural output growth. As discussed in the introduction section, when economies become integrated under a common currency, it will leave the policy responsibility of addressing region-specific shocks to the fiscal authority. Yet, it is not guaranteed that a consolidated fiscal system, even if in place, will be very effective in stabilizing idiosyncratic fluctuations.

Similarly to Fatás and Mihov (2001), we regress output volatility on government size. We gauge output volatility by standard deviations of the prefectural GDP growth for 1996-2009. For government size, the average values for the same period are used.

As highlighted by Rodrik (1998), the size of government is likely endogenous to output volatility. ${ }^{24}$ Thus, the regressor needs to be instrumented. Based on the results in section 4, we adopt the following variables as instruments: per capita income, population, area size, specialization index, distance from the major markets and prefectural GDP. ${ }^{25}$

Table 4 summarizes the estimation results. In the first column, we observe that the total size of government exerts a negative effect on the volatility of the prefectural output. Prefectures with a larger government size relative to its GDP tend to have less volatile output growth, which is in line with the findings of Fatás and Mihov (2001). When government size is measured in components, the estimates in columns 2 through 4 reveal that the government consumption is the source of the stabilizing effect. The $J$-statistics for the over-identification restrictions do not reject in any case the null hypothesis that the instruments are exogenous.

${ }^{24}$ The intra US investigation of Fatás and Mihov (2001) avoids this endogeneity problem because their measure of the state government size is determined federally without endogenous responses to the state output fluctuations.

${ }^{25}$ Prefectural GDP is included for the size effect of Alesina and Wacziarg (1998). 
Nonetheless, we recall that the output volatility should depend also on the extent to which the economy is exposed to external forces. Evidence on this is provided in Table 5. As displayed in column 1, when the prefectural GDP volatility is regressed on trade openness using the instruments, it obtains a highly significant positive coefficient to indicate that an increase in openness significantly adds to output volatility.

Once the effect of openness is controlled for, the effects of the government size variables turn statistically indistinguishable from zero as shown in columns 2-4 of the table. ${ }^{26}$ In contrast, the volatility-amplifying effect of trade openness is quite robust to the presence of the government size variables. Since openness and government size are highly correlated across prefectures (as confirmed in section 4), it is hard to clearly separate their influences on the output volatility. Nevertheless, the coefficient and adjusted r-squares estimates in Tables 4 and 5 as a whole suggest that regarding the output volatility the government size variables contain relatively little information that adds to what the openness variable captures. Thus, we interpret the results that under the current vertical fiscal system, the implications of government size for local output stabilization are rather limited.

\subsection{Fiscal versus market channels of risk sharing}

From welfare perspectives, it is desirable to reduce output volatility. It is equally important to smooth disposable income paths when volatility is inevitable. Even though the empirical results in sub-section 5.1 suggest that government may not exert direct effects on regional GDP fluctuations, it may still be able to enhance households' welfare by providing inter-regional risk-sharing arrangements using the taxes and transfers. In this sub-section, we estimate and compare the government and market contributions to

${ }^{26}$ In no cases the $J$-statistics reject the null of exogenous instruments. 
the inter-prefectural risk sharing.

There are alternative channels via which residents of different regions can pool risks to smooth their consumption. Asdrubali et al. (1996) notes three channels in analyzing the inter-US state risk sharing: capital market for cross-ownership of productive assets; the federal tax and transfer system; and lending and borrowing via credit markets. Previous studies report various estimates of the tax and transfer contributions to inter-regional risk sharing for the US, Canada, and European countries. ${ }^{27}$ For the US, some estimates (European Commission, 1977; Sala-i-Martin and Sachs, 1992) suggest that the share of the state-provided insurance is substantial at 30 percent or higher, while others (Asdrubali et al., 1996; Obstfeld and Peri, 1998; Fatás, 1998) report more humble estimates pointing to 10 to 13 percent. $^{28}$

For Japan, the 1975-1999 estimates by Fujiki and Nakakuki (2005) suggest that about 10 percent of idiosyncratic shocks are smoothed by the fiscal channel. ${ }^{29}$ It is noted that our 1996-2009 data encompasses rather different phases of the Japanese economy. The economic landscape shaped by deflation, stagnation, and global financial instability differs drastically from that in the eras of oil shocks and bubble economy included in the previous estimates. Table A-2 in the appendix compares several economic indicators between 1975-1999 and 1996-2009. It is evident from the table that the economic environment surrounding Japanese households were strikingly different

27 In addition to those cited in the main text, see Atkeson and Bayoumi (1993), von Hagen (1993), Bayoumi and Masson (1995), and Sørensen and Yosha (1998). von Hagen (2000) provides an excellent review of the literature.

28 The European commission (1977) reports equally high or even higher estimates for France, Germany, and Italy.

29 For 1975-1993, Kalemli-Ozcan et al. (2003) also estimates that about 97 percent of the idiosyncratic shocks in Japan are insured. While the contribution of capital market is estimated 21.6 percent, the breakdown between the fiscal and credit channels are not specified. Also, via the metric of consumption correlations, van Wincoop (1995) compares the risk sharing in Japan to that across the OECD countries. 
between the two periods. Thus, it is worth providing new estimates to examine if the shifts in the environment have altered the relative importance of the government versus market contributions to the interregional risk sharing.

We consider the following GDP accounting identity noted in Asdrubali et al. (1996)

$$
G D P_{i, t} \equiv \frac{G D P_{i, t}}{G P I_{i, t}} \cdot \frac{G P I_{i, t}}{D I_{i, t}} \cdot \frac{D I_{i, t}}{F C_{i, t}} \cdot F C_{i, t},
$$

for which GPI includes the net factor payment vis-à-vis other prefectures in the current context, DI is the income after taxes and transfers, FC is the final (both private and government) consumption, and all are in per capita terms. Based on (3), we estimate the panel regression equation

$$
\Delta X_{i, t}=\alpha_{t}+\beta \Delta \ln G D P_{i, t}+\varepsilon_{i, t},
$$

for which $\Delta X_{i, t}$ takes three alternatives: (a) $\Delta \ln G D P_{i, t}-\Delta \ln G P I_{i, t}$; (b) $\Delta \ln G P I_{i, t}-\Delta \ln D I_{i, t}$; and (c) $\Delta \ln D I_{i, t}-\Delta \ln F C_{i, t}$. The slope coefficients gauge the extents of GDP fluctuations smoothed, respectively, by (a) capital market (i.e. claims to output in other prefectures); (b) tax and transfer system; and (c) credit market (i.e. lending and borrowing) on average, respectively. ${ }^{30}$ The difference between unity and the sum of the three coefficient estimates indicates the share of the output fluctuations that remain unsmoothed to result in consumption fluctuations.

Since errors of the three equations may be correlated, for efficiency we estimate (4) as a system of equations by the seemingly unrelated regression (SUR) method. Table 6 presents the SUR estimates. About 10 percent of annual fluctuations of prefectural GDP are smoothed by net factor income arising from cross-prefecture ownership of

30 The year specific constant term in (4) absorbs the effects that are common to all prefectures but vary by year. 
productive assets. The contribution of the tax and transfer system is around 14 percent. By far the most dominant channel for consumption smoothing in the face of regional GDP fluctuations is saving and dissaving. The credit market channel has a lion's share reaching 66 percent. After the three channels, about 10 percent of per capita prefectural GDP fluctuations remain unsmoothed to generate consumption fluctuations.

Compared to the previously reported 1975-1999 estimates, the contribution of the fiscal channel shows a noticeable rise from 10 to 14 percent. On the other hand, capital market exhibits a substantial decline in its share from 20 to 10 percent, presumably reflecting the effects of the burst of the bubble market. Credit market has become even more dominant in shock absorption by extending its share from 60 to 66 percent.

Our estimate of the share of the Japanese tax and transfer channel turns out very close to 13 percent estimate by Asdrubali et al. (1996) for the US federal government. A crucial difference is found in the relative importance of capital market smoothing and credit market smoothing. Specifically, Asdrubali et al. (1996) finds that about 40 to 50 percent of the US state output fluctuations are smoothed via capital market while the corresponding share for credit market is around 20 percent. In contrast, our results reveal the stunning dominance of the credit market channel in the intra-Japan risk sharing. Japanese households cope with regional output fluctuations primarily by saving and dissaving. The finding is consistent with the other evidence that Japan's aggregate saving rate is substantially higher than the US counterpart (Hayashi, 1986) and the share of equities in household wealth is significantly lower in Japan than most other G7 countries (Horioka, 2012). ${ }^{31}$

\footnotetext{
31 It is interesting to observe that our estimate also closely matches the share of debt in Japan's total international assets estimated by Rogoff and Tashiro (2014).
} 


\section{Conclusions}

Government is often considered the safe sector of an open economy that plays a role of an insulator from external shocks. Since liberated flows of goods and services make economies more interdependent and hence more exposed to external risks, market liberalization may paradoxically generate a greater demand for government intervention as Rodrik (1998; 2011) argues.

Trade liberalization is typically accompanied by financial market development (Svaleryd and Vlachos, 2002), which spurs the financial side of market integration. As economic integration advances, residents in different regions come to share not only a common product market but also an integrated financial market. Consequently, households will be better equipped with market tools to diversify their income portfolios to insure themselves against risks.

Integration is not necessarily restricted to markets, and it may proceed also on the policy grounds. If economic integration is deepened by fiscal consolidation, households in different economies can pool risks via interregional taxes and transfers. To the extent that the fiscal system contributes to reduction of the adverse effects of income shocks experienced by residents, the government functions as a provider of social insurance.

Using Japan's regional income accounting and public finance data, we have examined the determinants and implications of government size under full economic integration. Our empirical results suggest that, unlike international cases, regional economies with a greater trade exposure tend to have a smaller size of government. The negative association seems to manifest that government and markets play substitutive roles across the fully integrated economies, unlike the complementary ones Rodrik (1998; 2011) notes for economies in the process of liberalization and integration. 
We find limited evidence on the effects of government size on regional output stabilization. While it is unambiguous that greater trade openness leads to more volatile output, prefectural differences in government size do not significantly determine differences in output volatility once the extent of openness is held constant. In enabling residents of different prefectures to pool risks of regional fluctuations, the estimated contributions of the fiscal instruments and those of the capital market are approximately 14 percent and 10 percent, respectively. In dealing with the regional output fluctuations, Japanese households rely heavily on credit markets (i.e. savings and loans).

What implications or lessons, if any, may be drawn from our findings? The significant negative government-openness association, in contrast to the previous positive international evidence, implies that part of the state-market relationship is transformed as economies become fully integrated with each other. In other words, the paradoxical positive association Rodrik (1998) highlights can be a transitory phenomenon that eventually disappears as economic integration reaches a higher stage.

Also, our findings imply that fiscal integration, even if introduced to a currency union, may not have stunning effects in regional output stabilization or risk sharing across member states. In fact, our Japanese estimates along with the previous US estimates indicate that integrated financial (i.e. capital and credit) markets play a more important role. 


\section{Data Appendix}

\section{Sources}

The data used in this study are obtained from the following two sources:

Annual Report on Prefectural Accounts 2012 CD-ROM, Department of National Accounts, Economic and Social Research Institute, Cabinet Office, Government of Japan.

Regional Statistics Database, Official Statistics of Japan.

\section{Notes}

While the Annual Report contains both nominal and real data, real series have an advantage of being free from possible cross-prefectural difference in relative price of government purchases. We thus use the real data.

Data on the disposable income (DI) are available only in nominal figures. We convert them into real series using the prefectural GDP deflators. Also, there are a couple of prefecture-specific incidents of missing observations. First, the observations on Tokyo's DI are missing altogether. We obtain the 2001-2009 nominal figures from Tokyo Metropolitan Government's site (http://www.toukei.metro.tokyo.jp). These figures are then converted into real terms using Tokyo's GDP deflator. Secondly, Aichi prefecture's export and import are available only in nominal figures. They are also converted into real series using Aichi's prefectural GDP deflator.

\section{Sectors for the specialization index}

The specialization index in sub-section 4.2 is constructed by using the output data on the following sectors:

\section{A. Industries}

1. Agriculture, forestry and fishing

1) Agriculture, 2) Forestry, 3) Fishing

2. Mining

3. Manufacturing

1) Food products and beverages, 2) Textiles, 3) Pulp, paper and paper products,

4) Chemicals, 5) Petroleum and coal products, 6) Non-metallic mineral products,

7) Primary metal, 8) Fabricated metal products, 9) Machinery, 10) Electrical machinery, equipment and supplies, 11) Transport equipment, 12) Precision instruments, 13) Others 
4. Construction

5. Electricity, gas and water supply

1) Electricity supply, 2) Gas and water supply

6. Wholesale and retail trade

7. Finance and insurance

8. Real estate

9. Transport and communications

10. Service activities

B. Producers of government services

1. Electricity, gas and water supply

2. Service activities

3. Public administration

C. Producers of private non-profit services to households

1. Service activities

\section{Inter-prefectural distance}

The inter-prefectural distance is measured by the geographical distance between the prefectural capitals using the program provided by the Geospatial Information Authority of Japan, Ministry of Land, Infrastructure, Transport and Tourism.

\section{Neighboring population size}

Neighboring population size is measured by the sum of population of all neighboring prefectures. Neighboring prefectures are defined to be those that share prefectural borders on ground. If prefectures are separated by the ocean but are connected by bridges or tunnels, they are also considered neighboring prefectures. For an island prefecture of Okinawa, the nearest prefecture of Kagoshima is considered as a neighbor. 
Table A-1. List of the prefectures

\begin{tabular}{llll}
\hline 1 & Hokkaido* & 25 & Shiga \\
2 & Aomori & 26 & Kyoto \\
3 & Iwate & 27 & Osaka* \\
4 & Miyagi & 28 & Hyogo* \\
5 & Akita & 29 & Nara \\
6 & Yamagata & 30 & Wakayama \\
7 & Fukushima & 31 & Tottori \\
8 & Ibaraki & 32 & Shimane \\
9 & Tochigi & 33 & Okayama \\
10 & Gunma & 34 & Hiroshima \\
11 & Saitama* & 35 & Yamaguchi \\
12 & Chiba* & 36 & Tokushima \\
13 & Tokyo* & 37 & Kagawa \\
14 & Kanagawa* & 38 & Ehime \\
15 & Niigata & 39 & Kochi \\
16 & Toyama & 40 & Fukuoka* \\
17 & Ishikawa & 41 & Saga \\
18 & Fukui & 42 & Nagasaki \\
19 & Yamanashi & 43 & Kumamoto \\
20 & Nagano & 44 & Oita \\
21 & Gifu & 45 & Miyazaki \\
22 & Shizuoka* & 46 & Kagoshima \\
23 & Aichi* & 47 & Okinawa \\
24 & Mie & & \\
\hline & & & \\
\hline
\end{tabular}

Notes: * indicates the ten most populated prefectures. 
Table A-2. Annual rate of changes in Japan's macroeconomic indicators

\begin{tabular}{lll}
\hline & $1975-1999$ & $1996-2009$ \\
\hline Real GDP & 3.22 & 0.54 \\
Household consumption expenditure & 3.07 & 0.74 \\
Consumer price index & 2.98 & -0.95 \\
Nikkei average & 8.48 & -1.47 \\
\hline
\end{tabular}

Notes: The entries indicate the average annual rates of changes of the variables noted in the first column for the corresponding periods. All entries are in percentage terms.

Nikkei averages are obtained from http://indexes.nikkei.co.jp/en/nkave. 


\section{Reference:}

Abizadeh, Sohrab and John Gray. 1985. Wagner’s Law: A Pooled Time-Series CrossSection Comparison, National Tax Journal, 88, 209-218.

Alesina, Alberto and Romain Wacziarg. 1998. Openness, country size and government. Journal of Public Economics, 69, 305-321.

Asdrubali, Pierfederico, Bent E. Sørensen, and Oved Yosha. 1996. Channels of interstate risk sharing: United States 1963-1990. Quarterly Journal of Economics, 111, 1081-1110.

Atkeson, Andrew and Tamim Bayoumi. 1993. Do private capital markets insure regional risk? Evidence from the United States and Europe. Open Economies Review, 4, 303-324.

Backus, David K., Patrick J. Kehoe, and Finn E. Kydland. 1992. International real business cycles. Journal of Political Economy, 100 (4), 745-775.

Bayoumi, Tamim and Paul R. Masson. 1995. Fiscal flows in the United States and Canada: Lessons for monetary union in Europe. European Economic Review, 39, 253-274.

Benarroch, Michael and Manish Pandey. 2012. The relationship between trade openness and government size: Does disaggregating government expenditure matter? Journal of Macroeconomics, 34, 239-252.

Bordo, Michael B., Lars Jonung and Agnieszka Markiewicz. 2013. A fiscal union for the Euro: Some lessons from history. CESifo Economic Studies, 59, 449-488.

Brückner, Markus, Alberto Chong, and Mark Gradstein. 2012. Estimating the permanent income elasticity of government expenditures: Evidence on Wagner's law based on oil price shocks. Journal of Public Economics, 96, 1025-1035.

Brückner, Markus and Anita Tuladhar. 2013. Local government spending multipliers and financial distress: Evidence from Japanese prefectures. Economic Journal, 
124, 1279-1316.

Easterly, William and Sergio Rebelo. 1993. Fiscal policy and economic growth: An empirical investigation. Journal of Monetary Economics, 32, 417-458.

European Commission. 1977. Report of the Study Group on the Role of Public Finance in European Integration, Vol. I and II, Studies: Economic and Financial Series A13 and B13. Brussels.

Fatás, Antonio. 1998. Does EMU need a fiscal federation? Economic Policy, 13, 165-203.

Fatás, Antonio and Ilian Mihov. 2001. Government size and automatic stabilizers: international and intranational evidence. Journal of International Economics, 55, 3-28.

Feldstein, Martin and Charles Horioka. 1980. Domestic saving and international capital flows, Economic Journal, 90, 314-329

French, Kenneth and James Poterba. 1991. International diversification and international equity markets. American Economic Review, 81, 222-226.

Fujiki, Hiroshi and Masayuki Nakakuki. 2005. Asymmetric shocks and regional risk sharing: Evidence from Japan. Monetary and Economic Studies, May, 31-60.

Galí, Jordi. 1994. Government size and macroeconomic stability. European Economic Review, 38, 117-132.

Hayashi, Fumio. 1986. Why is Japan's saving rate so apparently high? Stanley Fischer (ed.), NBER Macroeconomics Annual 1986, Volume 1, 147-234, MIT Press, Cambridge MA.

Heller, Peter S. and Jack Diamond. 1990. International Comparisons of Government Expenditure Revisited: The Developing Countries, 1975-1986. Occasional Paper, n. 69. Washington, D. C.: International Monetary Fund. 
Horioka, Charles Yuji. 2012. Are Japanese households financially healthy, and if so why? A group of seven (G7) comparison. Discussion Paper No. 859, The Institute of Economic and Social Research, Osaka University.

Kalemli-Ozcan, Sebnem, Bent E. Sørensen and Oved Yosha. 2003. Risk sharing and industrial specialization: Regional and international evidence. American Economic Review, 93, 903-918.

Kimakova, Alena. 2009. Government size and openness revisited: The case of financial globalization. Kyklos, 62, 394-406.

Krugman, Paul. 1991. Geography and trade. MIT Press, Cambridge MA.

Ministry of Internal Affairs and Communications. 2014. FY2012 Settlement: White Paper on Local Public Finance 2014.

Oates, Wallace E. 1972. Fiscal federalism. New York: Harcourt Brace Jovanovich.

Oates, Wallace E. 1999. An essay on fiscal federalism. Journal of Economic Literature, 37, 1120-1149.

Obstfeld, Maurice and Giovanni Peri. 1998. Regional nonadjustment and fiscal policy. Economic Policy, 13, 207-259.

Persson, Torsten and Guido Tabellini. 1996. Federal fiscal constitutions: Risk sharing and moral hazard. Econometrica, 64, 623-646.

Persson, Torsten and Guido Tabellini. 1999. The size and scope of government: Comparative politics with rational politician. European Economic Review, 43, 699-735.

Ram, Rati. 1987. Wagner's hypothesis in time-series and cross-section perspectives: Evidence from "real” data for 115 countries. Review of Economics and Statistics, 69, 194-204.

Ram, Rati. 2009. Openness, country size, and government size: Additional evidence 
from a large cross-country panel. Journal of Public Economics, 93, 213-218.

Rodrik, Dani. 1998. Why do more open economies have bigger governments? Journal of Political Economy, 106 (5), 997-1032.

Rodrik, Dani. 2011. The globalization paradox. W. W. Norton\& Company, New York, N.Y.

Rogoff, Kenneth S. and Takeshi Tashiro. 2014. Japan's exorbitant privilege. RIETI Discussion Paper Series 14-E-047. The Research Institute of Economy, Trade and Industry.

Sala-i-Martin, Xavier and Jeffery Sachs. 1992. Fiscal federalism and optimum currency areas: Evidence for Europe from the United States. In Matthew B. Canzoneri, Vittorio Grilli, and Paul R. Masson (eds.), Establishing a central bank: Issues in Europe and lessons from the US, Cambridge University Press, Cambridge, UK.

Sato, Motohiro. 2002. Intergovernmental transfers, governance structure and fiscal decentralization. Japanese Economic Review, 53 (1), 55-76.

Shelton, Cameron A. 2007. The size and composition of government expenditure. Journal of Public Economics, 91, 2230-2260.

Svaleryd, Helena and Jonas Vlachos. 2002. Markets for risk and openness to trade: how are they related? Journal of International Economics, 57, 369-395.

Sørensen, Bent E. and Oved Yosha. 1998. International risk sharing and European monetary unification. Journal of International Economics, 45, 211-238.

Tait, Alan A. and Peter S. Heller. 1982. International Comparisons of Government Expenditure. Occasional Paper, n. 10. Washington, D. C.: International Monetary Fund.

van Wincoop, Eric. 1995. Regional risk sharing. European Economic Review, 39, 1545-1567. 
von Hagen, Jürgen. 1993. Monetary union and fiscal union: A perspective from fiscal federalism. In Paul R. Masson and Mark P. Taylor (eds.), Policy issues in the operation of currency unions, Cambridge University Press, Cambridge, UK.

von Hagen, Jürgen. 2000. Fiscal policy and intranational risk sgaring. In Gregory D. Hess and Eric van Wincoop (eds.), Intra-national Macro-economics, Cambridge University Press, Cambridge, UK. 
Table 1. Determinants of government size

\begin{tabular}{lllll}
\hline & \multicolumn{2}{l}{ Dependent variable: Measures of government size } & Gov. investment \\
\cline { 2 - 4 } & Total & Consumption & Public investment & $-.022^{* *}$ \\
Openness & $-.089^{* *}$ & $-.063^{* *}$ & $-.025^{* *}$ & $(.004)$ \\
Per capita GDP & $(.018)$ & $(.015)$ & $(.005)$ & -.011 \\
& $-.176^{* *}$ & $-.159^{* *}$ & -.017 & $(.013)$ \\
Population & $(.063)$ & $(.055)$ & $(.013)$ & $-.013^{* *}$ \\
& $-.044^{* *}$ & $-.030^{* *}$ & $-.013^{* *}$ & $(.002)$ \\
Area & $(.006)$ & $(.005)$ & $(.002)$ & $.004^{*}$ \\
& .002 & -.001 & $.004^{\dagger}$ & $(.002)$ \\
Dependency ratio & $(.008)$ & $(.007)$ & $(.002)$ & -.068 \\
& .043 & .040 & .002 & $(.111)$ \\
Constant & $(.320)$ & $(.268)$ & $(.124)$ & $.260^{* *}$ \\
Adjusted $\mathrm{R}^{2}$ & $1.193^{* *}$ & $.949 * *$ & $.243^{* *}$ & $(.071)$ \\
\hline
\end{tabular}

Notes: The estimation results of (1) in the main text are summarized. The columns under headings “Total”, "Consumption”, "Public investment”, and "Gov. investment" contain the estimates when government size is measured by the prefectural GDP ratios of the total government expenditure, government final consumption, gross fixed public capital formation, and gross fixed government capital formation, respectively. $* *, *$ and ${ }^{\dagger}$ indicate statistical significance at the 1,5 , and 10 percent levels, respectively. Heteroskedastic-robust standard errors are provided in parentheses. The number of observations is 47 for all specifications. 
Table 2. Determinants of government size

\begin{tabular}{lllll}
\hline & \multicolumn{2}{l}{ Dependent variable: Measures of government size } & Gov. investment \\
\cline { 2 - 4 } & Total & Consumption & Public investment & $-.022^{* *}$ \\
Openness & $-.094^{* *}$ & $-.064^{* *}$ & $-.027^{* *}$ & $(.005)$ \\
Per capita GDP & $(.016)$ & $(.013)$ & $(.005)$ & $-.023^{*}$ \\
Population & $-.266^{* *}$ & $-.227^{* *}$ & $-.035^{*}$ & $(.011)$ \\
& $(.050)$ & $(.051)$ & $(.014)$ & $-.014^{* *}$ \\
Area & $-.032^{* *}$ & $-.029^{* *}$ & $-.014^{* *}$ & $(.002)$ \\
& $(.006)$ & $(.006)$ & $(.002)$ & $.005^{* *}$ \\
Dependency ratio & .003 & .0005 & $.005^{*}$ & $(.002)$ \\
Specialization & $(.007)$ & $(.006)$ & $(.002)$ & -.061 \\
Neighbors & .191 & .026 & -.002 & $(.107)$ \\
& $(.262)$ & $(.225)$ & $(.123)$ & $.048^{*}$ \\
Distance & $.255^{* *}$ & $.146^{*}$ & $.055^{*}$ & $(.020)$ \\
Constant & $(.080)$ & $(.061)$ & $(.022$ & .003 \\
Adjusted R $\mathrm{R}^{2}$ & -.005 & -.003 & .003 & $(.002)$ \\
\hline
\end{tabular}

Notes: The estimation results of (1) in the main text are summarized. The columns under headings "Total”, "Consumption”, "Public 
investment”, and "Gov. investment” contain the estimates when government size is measured by the prefectural GDP ratios of the total government expenditure, government final consumption, gross fixed public capital formation, and gross fixed government capital formation, respectively. $* *, *$ and ${ }^{\dagger}$ indicate statistical significance at the 1,5 , and 10 percent levels, respectively. Heteroskedastic-robust standard errors are provided in parentheses. The number of observations is 47 for all specifications. 
Table 3. Size of local governments by revenue sources

\begin{tabular}{|c|c|c|c|c|c|c|}
\hline & \multicolumn{2}{|c|}{ Local revenue } & \multicolumn{2}{|c|}{$\underline{\text { Transfer: LAT }}$} & \multicolumn{2}{|c|}{ Transfer: NTD } \\
\hline & 1 & 2 & 3 & 4 & 5 & 6 \\
\hline \multirow[t]{2}{*}{ Openness } & $-.344^{\dagger}$ & -.253 & .003 & .011 & $-.048 *$ & $-.032^{\dagger}$ \\
\hline & (.199) & $(.151)$ & $(.013)$ & $(.016)$ & $(.021)$ & $(.017)$ \\
\hline \multirow[t]{2}{*}{ Per capita GDP } & $1.776^{*}$ & $1.612 *$ & $-.097^{\dagger}$ & -.019 & .155 & $.164^{*}$ \\
\hline & $(.881)$ & $(.716)$ & $(.053)$ & $(.057)$ & $(.093)$ & $(.068)$ \\
\hline \multirow[t]{2}{*}{ Population } & $.123^{*}$ & $.104 *$ & .007 & .003 & $.023 * *$ & $.019 * *$ \\
\hline & $(.051)$ & $(.044)$ & $(.008)$ & $(.008)$ & $(.008)$ & $(.006)$ \\
\hline \multirow[t]{2}{*}{ Area } & $-.129 *$ & $-.102^{\dagger}$ & .010 & .010 & $-.019 *$ & $-.016^{\dagger}$ \\
\hline & $(.050)$ & $(.057)$ & (.009) & $(.009)$ & $(.007)$ & $(.008)$ \\
\hline \multirow[t]{2}{*}{ Dependency ratio } & $-4.162^{\dagger}$ & $-3.610^{\dagger}$ & -.178 & -.098 & $-.598^{\dagger}$ & $-.498^{\dagger}$ \\
\hline & (2.319) & $(2.092)$ & $(.383)$ & $(.347)$ & $(.320)$ & $(.286)$ \\
\hline \multirow[t]{2}{*}{ Specialization } & - & $1.412 *$ & - & -.041 & - & $.158^{*}$ \\
\hline & & $(.672)$ & & $(.086)$ & & $(.075)$ \\
\hline \multirow[t]{2}{*}{ Neighbors } & - & .064 & - & $.015^{\dagger}$ & - & $.012^{\dagger}$ \\
\hline & & $(.055)$ & & $(.007)$ & & $(.006)$ \\
\hline \multirow[t]{2}{*}{ Distance } & - & .168 & - & $.058 * *$ & - & $.042 *$ \\
\hline & & $(.138)$ & & $(.021)$ & & $(.016)$ \\
\hline \multirow[t]{2}{*}{ Constant } & .425 & -2.649 & .021 & $-.800 *$ & .135 & $-.532^{\dagger}$ \\
\hline & $(1.227)$ & (2.007) & $(.256)$ & $(.380)$ & $(.204)$ & $(.276)$ \\
\hline Adjusted $\mathrm{R}^{2}$ & .721 & .784 & .120 & .184 & .635 & .718 \\
\hline
\end{tabular}


Notes: The columns under headings "Local revenue”, “Transfer: LAT”, and “Transfer: NTD” contain the estimates when government size is measured by the prefectural GDP ratios of the independently-attained revenue by local governments, local allocation tax grant transferred from the central government, and national treasury disbursement, respectively. ${ }^{* *},{ }^{*}$ and ${ }^{\dagger}$ indicate statistical significance at the 1, 5, and 10 percent levels, respectively. Heteroskedastic-robust standard errors are provided in parentheses. The number of observations is 47 for all specifications. 
Table 4. Output volatility and government size

\begin{tabular}{|c|c|c|c|c|}
\hline & \multicolumn{4}{|c|}{ Dependent variable: Output volatility } \\
\hline & 1 & 2 & 3 & 4 \\
\hline \multirow[t]{2}{*}{ Government total } & $-.032 *$ & & & \\
\hline & $(.014)$ & & & \\
\hline \multirow[t]{2}{*}{ Government consumption } & & $-.054 * *$ & - & - \\
\hline & & $(.021)$ & & \\
\hline \multirow[t]{2}{*}{ Public investment } & & - & -.069 & - \\
\hline & & & $(.043)$ & \\
\hline \multirow[t]{2}{*}{ Government investment } & & - & - & -.069 \\
\hline & & & & $(.045)$ \\
\hline \multirow[t]{2}{*}{ Constant } & $.033 * *$ & $.035 * *$ & $.029 * *$ & $.029 * *$ \\
\hline & $(.004)$ & $(.004)$ & $(.003)$ & $(.002)$ \\
\hline$J$-statistics & 1.983 & 1.797 & 2.271 & 2.287 \\
\hline Adjusted $\mathrm{R}^{2}$ & .135 & .167 & .069 & .056 \\
\hline
\end{tabular}

Notes: The instrumental variable estimates are displayed. The dependent variable is the standard deviations of the prefectural GDP growth. The instruments are per capita income, population, area size, specialization index, distance from the major markets and prefectural GDP. The row labeled $J$-statistics contains the $\chi^{2}$ test statistics for the over-identification restrictions. ${ }^{* *}$ and $*$ indicate statistical significance at the 1 and 5 percent levels, respectively. Heteroskedastic-robust standard errors are provided in parentheses. The number of observations is 47 for all specifications. 
Table 5. Output volatility, openness, and government size

\begin{tabular}{|c|c|c|c|c|c|}
\hline & \multicolumn{5}{|c|}{ Dependent variable: Output volatility } \\
\hline & 1 & 2 & 3 & 4 & 5 \\
\hline \multirow[t]{2}{*}{ Openness } & $.013^{* *}$ & $.013 * *$ & $.012 * *$ & $.014^{* *}$ & $.014^{* *}$ \\
\hline & $(.003)$ & $(.004)$ & $(.004)$ & $(.004)$ & $(.004)$ \\
\hline \multirow[t]{2}{*}{ Government total } & & -.003 & & & \\
\hline & & $(.016)$ & & & \\
\hline \multirow[t]{2}{*}{ Government consumption } & & & -.009 & - & - \\
\hline & & & $(.025)$ & & \\
\hline \multirow[t]{2}{*}{ Public investment } & & & - & .004 & - \\
\hline & & & & $(.042)$ & \\
\hline \multirow[t]{2}{*}{ Government investment } & & & - & - & .009 \\
\hline & & & & & $(.044)$ \\
\hline \multirow[t]{2}{*}{ Constant } & .006 & .008 & .010 & .006 & .005 \\
\hline & $(.004)$ & $(.009)$ & $(.010)$ & $(.007)$ & $(.007)$ \\
\hline$J$-statistics & .865 & 1.048 & 1.026 & 1.057 & 1.053 \\
\hline Adjusted $\mathrm{R}^{2}$ & .352 & .352 & .355 & .355 & .356 \\
\hline
\end{tabular}

Notes: The instrumental variable estimates are displayed. The dependent variable is the standard deviations of the prefectural GDP growth. The instruments are per capita income, population, area size, specialization index, distance from the major markets and prefectural GDP. The row labeled $J$-statistics contains the $\chi^{2}$ test statistics for the over-identification restrictions. ** and *indicate statistical significance at the 1 and 5 percent levels, respectively. Heteroskedastic-robust standard errors are provided in parentheses. The number of observations is 47 for all specifications. 
Table 6. Contributions to inter-prefectural risk sharing

\begin{tabular}{lll}
\hline & Dependent variable & Extents of smoothing (\%) \\
\hline Capital market & $\Delta \ln G D P_{i, t}-\Delta \ln G P I_{i, t}$ & 10.61 \\
Tax and transfer & $\Delta \ln G P I_{i, t}-\Delta \ln D I_{i, t}$ & $1.23)$ \\
& & 13.95 \\
Credit markets & $\Delta \ln D I_{i, t}-\Delta \ln F C_{i, t}$ & 66.00 \\
& & $(3.81)$ \\
\hline
\end{tabular}

Notes: The SUR estimates for (4) in the main text are reported in percentage terms. The numbers in parentheses are the standard errors. 